Brit. J. industr. Med., 1962, 19, 1.

\title{
THE SIZE OF COTTON DUST PARTICLES CAUSING BYSSINOSIS : AN ENVIRONMENTAL AND PHYSIOLOGICAL STUDY
}

\author{
BY \\ C. B. MCKERROW, S. A. ROACH, J. C. GILSON, and R. S. F. SCHILlinG \\ From the Medical Research Council, Pneumoconiosis Research Unit, Penarth, and the Department of \\ Occupational Health, London
}

(RECEIVED FOR PUBLICATION JULY 14, 1961)

Fourteen subjects of whom 12 were cotton mill blow- or card-room workers were exposed in a plastic tent for periods of three or four hours to airborne mill dust either of unrestricted size distribution (total dust) or containing only particles of less than $7 \mu$ (fine dust).

A significant fall in indirect maximum breathing capacity followed exposure to either total or fine dust in most experiments. The response to total dust usually appeared a little larger than to fine but the concentration of fine particles in the unfiltered air was rather higher. The changes in the single-breath nitrogen clearance index and the inspiratory airways resistance were less constant, but the general pattern followed that of the ventilatory capacity.

It is concluded that the fine fraction (under $7 \mu$ ) of cotton mill dust produces changes in respiratory function and may be alone responsible. The findings suggest a direct action by the dust on the smaller air passages and imply that to be completely effective dust suppression measures in cotton mills should remove fine dust.

Byssinosis has been recognized in the Lancashire cotton industry for over a century (Kay, 1831), but until recent years few studies have been made either of the environment producing it or of its physiological effects. In general it has been assumed that fine particles of cotton dust are responsible (Middleton, 1932; Prausnitz, 1936), although in a recent study Roach and Schilling (1960) found that the prevalence of byssinosis was more highly correlated with the concentration of dust particles of a size range of approximately $7 \mu-2 \mathrm{~mm}$.

The latter findings suggest that the site of action is in the upper respiratory tract and also that suppression of dust over $7 \mu$ may prevent the disease. However, the reduction in ventilatory capacity in byssinotic subjects on a Monday compared with a Thursday (Schilling, Hughes, Dingwall-Fordyce, and Gilson, 1955) and at the end of a working day (McKerrow, McDermott, Gilson, and Schilling, 1958) suggests that there may be an effect on the smaller airways producing either bronchospasm or oedema. If this is so, suppression of only the coarser dust will not be sufficient to prevent it.

In the present paper we compare the physiological effect of airborne mill dust of unrestricted size distribution with that containing particles below $7 \mu$ (fine dust). One of us (S.A.R.) had shown, in a pilot study, that subjects could be exposed to fine dust in a card-room by using a plastic tent with elutriators attached to the air inlet. Previous work has adequately demonstrated that physiological change during the day should not be expected in the absence of a specific environmental factor producing it (Gielen, 1957; McKerrow et al., 1958; Lewinsohn, Capel, and Smart, 1960).

\section{Methods}

Environment.-A plastic tent of 5 feet cube and capable of seating six people (Fig. 1) was used in the experiments. It was manufactured from heavy grade 20 thou. P.V.C. (polyvinyl chloride) sheet with welded edges and corners. It had transparent windows and entry was gained through a long slit with flaps in one side. It was supported by an inside framework of copper tubing connected with loosely fitting "Yorkshire corner tees". To prevent rupture of the floor the tent was mounted on a layer of carpet underfelt, and thick linoleum was laid inside. When the subjects were inside the tent it was sealed with Scotch tape and plasticine. It was furnished with a collapsible table and chairs, a fan, electric light, and a radio.

The tent was erected in a Lancashire cotton mill

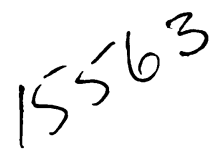




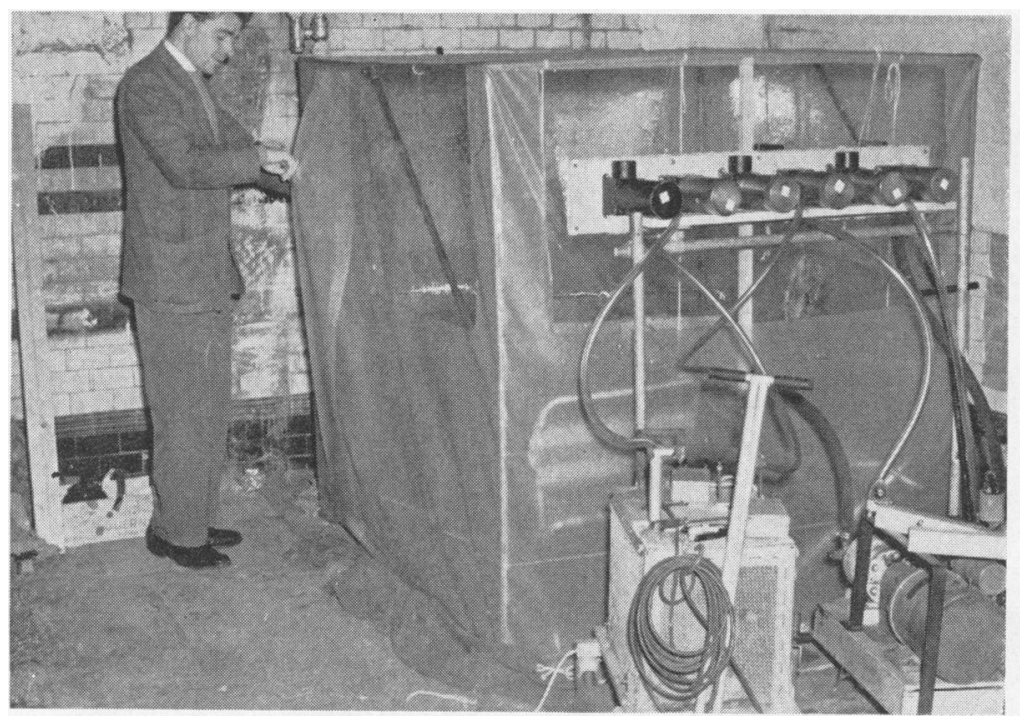

Fig. 1.-The tent showing the hexhlets for dust sampling and the air pumps.

spinning coarse counts. In the first series of tests it was connected to the settling chamber of the mill's trash removal system, and in the second it was placed in one of the card-rooms.

The tent was ventilated at 600 litres per minute by three 200 litres per minute suction pumps. The inlet either allowed unrestricted entry of air or it could be covered by two banks of three horizontal elutriators similar to those developed by Wright (1954) for the hexhlet (Fig. 2). These elutriators are stacks of parallel plates with the separation between plates such that all particles with an equivalent diameter of over $7 \cdot 1 \mu$ settle during passage over them and are retained. Thus when they were in use the occupants of the tent received filtered air containing none of the particles above $7 \mu$ but a progressively increasing proportion of the dust below this size (Roach and Schilling, 1960), but when the elutriators were removed dust of the whole size range

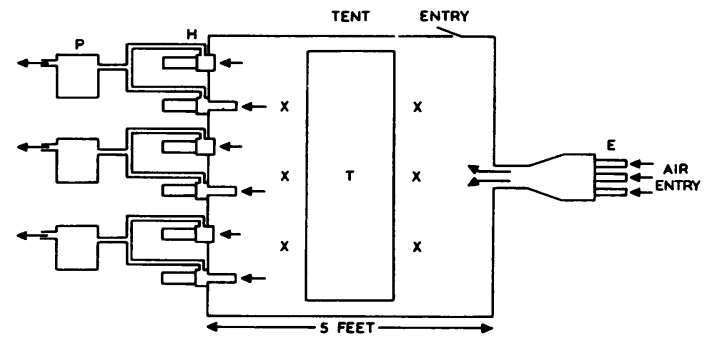

FIG. 2.-Diagram of whole equipment (plan). E: Detachable elutriators at the air inlet for removing coarse and medium dust : $\mathrm{T}$ : Table; $\mathrm{H}$ : Hexhlets for measuring dust in tent (Three have their elutriators removed for collecting total dust); P: Air pumps; X: Subjects. was breathed. The quantity of dust passing through the tent was measured by filter paper samplers in the inlet to the suction pump. In the first series of tests the activity of the dust as a smooth muscle contractor was measured on rat stomach preparations (Davenport and Paton, 1962).

Physiological Measurements. - Ventilatory capacity and nitrogen clearance were measured in the first series of tests, and ventilatory capacity and airways resistance in the second series.

(1) Ventilatory Capacity.-Ventilatory capacity was estimated from the volume expired in 0.75 of a second during a forced expiration using a spirometer with timer (McKerrow, McDermott, and Gilson, 1960). The mean of three measurements following two practice attempts was used. The results were corrected to body temperature and pressure saturated with water vapour (B.T.P.S.), and were multiplied by 40 to give the indirect maximum breathing capacity (I.M.B.C.) shown by Kennedy (1953) to be highly correlated with, and numerically similar to, the maximum voluntary ventilation (M.V.V.).

(2) Nitrogen Clearance Index.-The change in alveolar nitrogen concentration between the first $750 \mathrm{ml}$. and $1250 \mathrm{ml}$. of an expiration after a full breath of oxygen is used as an index of the inequality of ventilation in different parts of the lungs: the greater the inequality the greater is the rise in the nitrogen concentration during the expiration (Comroe and Fowler, 1951). The nitrogen concentration, measured by a nitrogen meter, was recorded with an ink writer on a drum mounted on the wheel of the spirometer measuring the expired volume (Olsen and Gilson, 1960). This greatly 
facilitated analysis by providing $\mathrm{N}_{2}$ concentration as ordinate and volume expired as abscissa on the record. Usually only one estimate of the clearance index was made on each occasion.

(3) The Airways Resistance.-The airways resistance (A.W.R.) on inspiration was measured by the multiple interrupter designed by Clements, Sharp, Johnson, and Elam (1959). Pressures at the mouth before and after the interruptions were measured on the same single channel capacitance manometer and recorded on a Mingograph recorder. It has been shown by Shephard (1959) that airways resistance by this method remains fairly constant over the middle half of a full inspiration or expiration. We therefore had the subjects breathe quietly through the apparatus, and assumed that changes in respiratory level were insufficient to influence the resistance values. As it is likely that an increase in resistance will be accompanied by some increase in the functional residual capacity, this method may tend to underestimate changes in airways resistance.

We were interested simply in changes in the resistance, and therefore it was sufficient to express it in "A.W.R. units" which were the ratio of the mouth pressure at the end of each interruption to that at the end of each corresponding period of air flow. Interruptions were made 10 times per second and 10 ratios were calculated at the middle of the inspiratory phase of each of three quiet respirations. Thus the final result for each subject on each occasion was a mean derived from 30 interruptions. This tedious method was thought preferable to making use of the side taps on the Clements interrupter because it avoided any possible error arising from the use of separate recorders for the two pressure measurements. It meant, however, that the pressure was measured a little later in each interruption than suggested by Clements.

\section{Experimental Plan}

First Series of Tests.-The tent was set up in a room adjoining the settling chamber of the mill's trash removal system and connected to it by 6 in. diameter trunking. The dust concentration within it was therefore much greater than that in the card-room as a whole.

Eight workers, all of whom had had at least 11 years in a cotton mill blowing or card-room, and four of whom complained of symptoms of byssinosis, and two of the authors, took part in the experiment. The tests were practised on a Friday, and the subjects divided into two groups, A and B (Table 1). On the Monday morning Group A reported at about 7 a.m., performed the I.M.B.C. and the nitrogen meter tests, and entered the tent for three hours where they were exposed to dust of the whole range of particle size (total dust). The physiological measurements were repeated on leaving the tent and at about 12 noon, 2 p.m., and 3.30 p.m. On Tuesday the tests were repeated on two occasions, about 9 a.m. and 5 p.m., and on Wednesday the procedure was the same as on Monday except that the elutriators were in position in the tent so that the subjects were exposed to fine dust alone. Thursday's measurements were a repetition of Tuesday's, and a final
TABLE 1

AGE, TOTAL EXPOSURE TO COTTON DUST, BYSSINOSIS GRADE, AND EXPERIMENTAL GROUPS OF THE SUBJECTS

\begin{tabular}{|c|c|c|c|c|}
\hline Subject & $\begin{array}{c}\text { Age } \\
\text { (years) }\end{array}$ & $\underset{\text { (years) }}{\text { Exposure }}$ & $\begin{array}{l}\text { Byssinosis } \\
\text { Grade* }\end{array}$ & $\begin{array}{c}\text { Experimental } \\
\text { Groups }\end{array}$ \\
\hline $\begin{array}{l}\text { H. M. } \\
\text { C. H. } \\
\text { E. M. } \\
\text { J. M. } \\
\text { R. S. } \\
\text { J. C. } \\
\text { L. A. } \\
\text { T. B. } \\
\text { T. W. } \\
\text { S. R. } \\
\text { N. L. } \\
\text { F. M. } \\
\text { J. S. } \\
\text { P. S. }\end{array}$ & $\begin{array}{l}34 \\
41 \\
41 \\
28 \\
47 \\
31 \\
36 \\
54 \\
53 \\
32 \\
54 \\
32 \\
35 \\
42\end{array}$ & $\begin{array}{r}18 \\
21 \\
12 \\
11 \\
0 \\
14 \\
20 \\
41 \\
37 \\
0 \\
38 \\
13 \\
12 \\
11\end{array}$ & $\begin{array}{l}0 \\
2 \\
2 \\
0 \\
\mathbf{N} \\
0 \\
1 \\
0 \\
2 \\
\mathbf{N} \\
2 \\
2 \\
\frac{1}{2} \\
0\end{array}$ & $\begin{array}{c}\text { A, C } \\
\text { A, C } \\
\text { A, C } \\
\text { A, C } \\
\text { A, C } \\
\text { B, D } \\
\text { B } \\
\text { B } \\
\text { B, D } \\
\text { B, D } \\
\text { C } \\
\text { D } \\
\text { D } \\
\text { D }\end{array}$ \\
\hline
\end{tabular}

* Byssinosis classification of Roach and Schilling (1960).

$\mathrm{N}=$ Two of the authors.

reading was made on Friday morning. During the whole period of the experiment the men were off work and avoided the mill card-rooms.

Group B carried out a similar procedure except that the dust exposures were on the afternoons of Monday and Wednesday and the first period was with fine dust. Subsequent tests were made at similar intervals after exposure except that on Tuesday and Thursday the observations were made at a similar time of day to Group A.

Second Series of Tests.-About eight weeks later the experiment was repeated with the tent set up in a card-room between two carding engines so that the dust concentrations should be similar to those normally encountered by card-room workers.

The subjects were six cotton workers who had taken part in the first experiment and four additional cotton workers, all of whom had had at least 11 years exposure to cotton dust, and the two authors. Six of the 10 cotton workers had symptoms of byssinosis (Table 1). The experimental design was similar except that the period of exposure was increased from three to four hours. The ventilatory capacity was measured three times daily and the airways resistance twice on each of the four days.

\section{Results}

Dust Concentrations.-From one to three dust samples were available during each experiment to show the total weight of the dust and that of its particles below $7 \mu$. In view of the small number of samples the mean figures (Table 2) give only an approximate estimate of the dust conditions in the tent. They suggest that there was generally a slightly higher concentration of the fine component when no elutriator was present.

In the first series four dust samples in each experiment were tested biologically. The results in Table 3 show that weight for weight there was no 
TABLE 2

DUST CONCENTRATIONS IN THE TENT

\begin{tabular}{|c|c|c|c|}
\hline & \multicolumn{2}{|c|}{$\begin{array}{l}\text { Exposure to Total Dust } \\
\left(\mathrm{mg} . / 100 \mathrm{~m}^{3}\right)\end{array}$} & \multirow{2}{*}{$\begin{array}{l}\text { Exposure to } \\
\text { Fine Dust* } \\
\text { (mg./100 m. }\end{array}$} \\
\hline & All Particles & Fine Particles & \\
\hline $\begin{array}{r}\text { First series: } \\
\text { Group A } \\
\text { Group B }\end{array}$ & $\begin{array}{l}380 \\
535\end{array}$ & $\begin{array}{l}130 \\
170\end{array}$ & $\begin{array}{l}135 \\
140\end{array}$ \\
\hline $\begin{array}{l}\text { Second series: } \\
\text { Group C } \\
\text { Group D }\end{array}$ & $\begin{array}{l}180 \\
135\end{array}$ & $\begin{array}{l}85 \\
95\end{array}$ & $\begin{array}{l}75 \\
60\end{array}$ \\
\hline
\end{tabular}

* The fineness of the dust in the tent was checked by collecting it in hexhlets with and without elutriators, and in the first series the proportion of the dust passing through the elutriators was $85 \%$ and in the second series $95 \%$.

TABLE 3

BIOLOGICAL ACTIVITY OF DUST MEASURED ON RAT STOMACH

(expressed as 5-hydroxytryptamine equivalents in nonograms per $\mathrm{mg}$. dust)

\begin{tabular}{l|c|c|c}
\hline \multirow{2}{*}{ Subjects } & \multicolumn{2}{|c|}{ Exposure to Total Dust } & Exposure to Fine Dust \\
\cline { 2 - 4 } & All Particles & Fine Particles & \\
\hline Group A & 2.0 & 1.6 & 1.3 \\
Group B & 1.3 & 1.9 & 1.6 \\
\hline
\end{tabular}

obvious difference in the activity of total and fine dust.

\section{Physiological Measurements}

First Series of Tests.-Table 4 gives the I.M.B.C. results for each subject throughout the days of

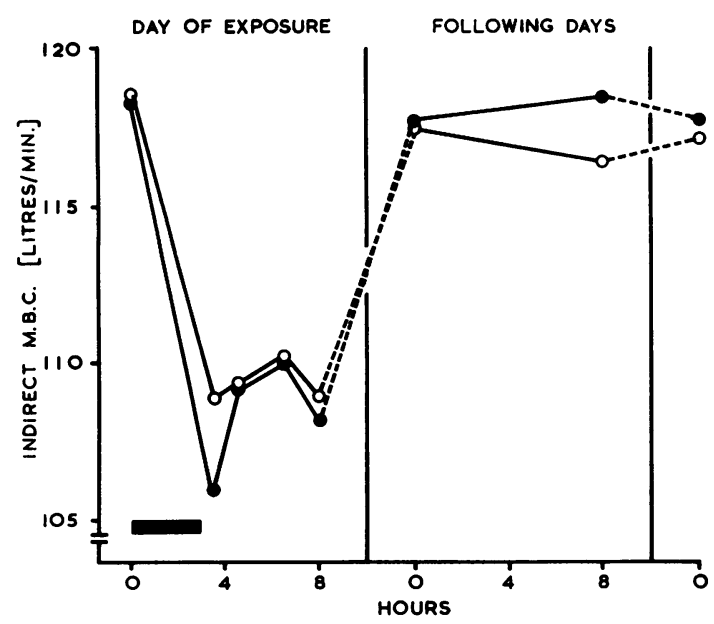

FIG. 3.-Change in I.M.B.C. (first series) caused by exposure to total dust $(O)$ and fine dust $(O)$. The period of exposure is indicated by the solid block. exposure alone, and Fig. 3 gives the average results over the whole period.

There was a significant fall in ventilatory capacity after exposure to both total and fine dust, and the two exposures did not differ significantly from each other. The initial falls in I.M.B.C. after exposure were:

Total dust: $12.4 \pm 2 \cdot 21 . / \mathrm{min} .(\mathrm{p}<0.001)$

Fine dust: $9.7 \pm 2.21 . / \mathrm{min} .(\mathrm{p}<0.001)$

(The standard errors are derived from the differences from subject to subject in the pattern of response over the whole period of study.) The effective standard error of a single I.M.B.C. result was $\pm 5.01 . / \mathrm{min}$.

In Fig. 3 the mean results of exposure to each type of dust have been plotted. Each point includes both Groups A and B and they have been spaced according to the intervals between tests on each day. As tests in both groups were made at similar times on the day following exposure, the interval after exposure is a little less in Group B subjects than in Group A, but recovery on these days is so nearly complete in all subjects that the combination of the two groups is justified.

The general similarity of the pattern of change in response to both total and fine dust is apparent: in both, the fall in ventilatory capacity persists for over four hours, and this delayed recovery is in accord with the clinical observation that the sensation of tightness in the mill worker persists into the evening after leaving the mill.

Table 5 shows the corresponding results for the nitrogen clearance index. There was considerable variation between individuals and the largest changes after dust were found in the three subjects whose I.M.B.C. was below 90 litres per minute.

T. W., a disabled man with the symptoms of both chronic bronchitis and byssinosis, showed the largest effects of exposure to the dust, a rise in nitrogen percentage of 1.6 with total dust and of 2.68 with fine. C. H. and T. B. also had considerable changes after fine dust. In the Groups $A$ and $B$ together a significant rise in the $\mathrm{N}_{2}$ index of $0.44 \%$ occurred in fine dust $(0.001<\mathrm{p}<0.01)$, but the rise of $0.13 \%$ in total dust was insignificant, and the difference between the two responses was also not significant. The effective standard error of a single result was $\pm 0.33 \%$.

It appears from these findings that the expired nitrogen test is, relative to the I.M.B.C., a less sensitive index of the effects of dust inhalation except in those subjects with considerable respiratory impairment.

Second Series of Tests.-The individual results of the ventilatory capacity tests on the days of exposure are given in Table 6. Group $\mathrm{C}$ which commenced 
TABLE 4

I.M.B.C. THROUGHOUT DAYS OF EXPOSURE TO TOTAL AND TO FINE DUST (First Series of Tests)

\begin{tabular}{|c|c|c|c|c|c|c|c|c|c|c|}
\hline \multirow[b]{3}{*}{ Group A } & \multicolumn{10}{|c|}{ I.M.B.C. (1./min.) } \\
\hline & \multicolumn{5}{|c|}{ Exposure to Total Dust } & \multicolumn{5}{|c|}{ Exposure to Fine Dust } \\
\hline & 7.30 a.m. & 10.45 a.m. & 12.00 noon & 2.00 p.m. & 3.30 p.m. & 7.30 a.m. & 10.45 a.m. & 12.00 noon & 2.00 p.m. & 3.30 p.m. \\
\hline $\begin{array}{l}\text { Subject: } \\
\text { H. M. } \\
\text { C. H. } \\
\text { E. M. } \\
\text { J. M. } \\
\text { R. S. }\end{array}$ & $\begin{array}{r}124 \cdot 0 \\
59 \cdot 3 \\
129 \cdot 0 \\
106.0 \\
156.3\end{array}$ & $\begin{array}{r}121 \cdot 0 \\
53 \cdot 3 \\
103 \cdot 0 \\
103 \cdot 0 \\
138.0\end{array}$ & $\begin{array}{r}127 \cdot 3 \\
52 \cdot 7 \\
109 \cdot 7 \\
106 \cdot 0 \\
134 \cdot 0\end{array}$ & $\begin{array}{r}121.0 \\
55.7 \\
108.7 \\
103.7 \\
137.7\end{array}$ & $\begin{array}{r}121 \cdot 3 \\
54 \cdot 0 \\
105 \cdot 3 \\
107 \cdot 3 \\
141 \cdot 3\end{array}$ & $\begin{array}{r}121.3 \\
57.3 \\
121.0 \\
101.7 \\
162.7\end{array}$ & $\begin{array}{r}110.7 \\
51.7 \\
113.0 \\
95.3 \\
156.0\end{array}$ & $\begin{array}{r}115.7 \\
49.0 \\
115.0 \\
100.7 \\
154.7\end{array}$ & $\begin{array}{r}112.7 \\
53.7 \\
113.0 \\
104.0 \\
147.0\end{array}$ & $\begin{array}{r}115 \cdot 7 \\
47.0 \\
113.3 \\
103.0 \\
145 \cdot 5\end{array}$ \\
\hline Mean & 114.9 & $103 \cdot 7$ & $105 \cdot 9$ & $105 \cdot 4$ & $105 \cdot 8$ & $112 \cdot 8$ & $105 \cdot 3$ & $107 \cdot 0$ & $106 \cdot 1$ & 104.9 \\
\hline Group B & 1.00 p.m. & 4.15 p.m. & 5.30 p.m. & 7.30 p.m. & 9.00 p.m. & 1.00 p.m. & 4.15 p.m. & 5.30 p.m. & 7.30 p.m. & 9.00 p.m. \\
\hline $\begin{array}{c}\text { Subject: } \\
\text { J.C. } \\
\text { L. A. } \\
\text { T. B. } \\
\text { T. W. } \\
\text { S. R. }\end{array}$ & $\begin{array}{r}143.0 \\
146.3 \\
84.7 \\
61.0 \\
173.0\end{array}$ & $\begin{array}{r}125 \cdot 7 \\
133.3 \\
68.7 \\
47.7 \\
165.0\end{array}$ & $\begin{array}{r}128 \cdot 7 \\
138 \cdot 0 \\
75 \cdot 7 \\
50 \cdot 7 \\
169 \cdot 0\end{array}$ & $\begin{array}{r}137 \cdot 7 \\
138 \cdot 5 \\
76 \cdot 7 \\
50 \cdot 0 \\
169 \cdot 3\end{array}$ & $\begin{array}{r}120 \cdot 7 \\
127 \cdot 3 \\
80 \cdot 0 \\
57 \cdot 7 \\
166 \cdot 3\end{array}$ & $\begin{array}{r}143 \cdot 3 \\
146 \cdot 7 \\
89 \cdot 3 \\
68 \cdot 7 \\
173 \cdot 7\end{array}$ & $\begin{array}{r}136.0 \\
139.0 \\
75.0 \\
50.7 \\
161.7\end{array}$ & $\begin{array}{r}133 \cdot 7 \\
136 \cdot 0 \\
78 \cdot 3 \\
50 \cdot 7 \\
159 \cdot 7\end{array}$ & $\begin{array}{r}134 \cdot 0 \\
139 \cdot 0 \\
82 \cdot 3 \\
54 \cdot 7 \\
161 \cdot 0\end{array}$ & $\begin{array}{r}126 \cdot 5 \\
128 \cdot 7 \\
84 \cdot 0 \\
57 \cdot 3 \\
168 \cdot 0\end{array}$ \\
\hline Mean & $121 \cdot 6$ & $108 \cdot 1$ & $112 \cdot 4$ & $114 \cdot 4$ & $110 \cdot 4$ & $124 \cdot 3$ & $112 \cdot 5$ & $111 \cdot 7$ & $114 \cdot 2$ & $112 \cdot 9$ \\
\hline$\underset{\text { mean }}{\text { Grand }}$ & $118 \cdot 3$ & 105.9* & $109 \cdot 2$ & 109.9 & $108 \cdot 1$ & 118.6 & $108 \cdot 9 *$ & $109 \cdot 4$ & $110 \cdot 2$ & $108 \cdot 9$ \\
\hline
\end{tabular}

* Falls in M.B.C. after both total and fine dusts are significant $(p<0.001)$.

with fine dust exposure on Monday afternoon had a similar composition to Group A with the addition of one man (N. L.) who had byssinosis symptoms. Significant falls in I.M.B.C. of 18.5 litres per minute and $16 \cdot 2$ litres per minute respectively followed exposure to total and fine dust $(p<0.001$.) Group D contained three people additional to Group B and they were relatively insensitive to either dust. There was a significant fall of 6.9 litres per minute following total dust $(0.001<\mathrm{p}<0.01)$,

TABLE 5

NITROGEN CLEARANCE INDEX THROUGHOUT DAYS OF EXPOSURE TO TOTAL AND TO FINE DUST (First Series of Tests)

\begin{tabular}{|c|c|c|c|c|c|c|c|c|c|c|}
\hline \multirow[b]{3}{*}{ Group A } & \multicolumn{10}{|c|}{ Change in Expired Nitrogen (\%) } \\
\hline & \multicolumn{5}{|c|}{ Exposure to Total Dust } & \multicolumn{5}{|c|}{ Exposure to Fine Dust } \\
\hline & 7.30 a.m. & 10.45 a.m. & 12.00 noon & 2.00 p.m. & 3.30 p.m. & 7.30 a.m. & 10.45 a.m. & 12.00 noon & 2.00 p.m. & 3.30 p.m. \\
\hline $\begin{array}{c}\text { Subject: } \\
\text { H. M. } \\
\text { C. H. } \\
\text { E. M. } \\
\text { J. M. } \\
\text { R. S. }\end{array}$ & $\begin{array}{l}0.63 \\
2.05 \\
1.00 \\
0.63 \\
0.37\end{array}$ & $\begin{array}{l}0.63 \\
1.54 \\
0.83 \\
0.52 \\
0.40\end{array}$ & $\begin{array}{l}0.62 \\
1.75 \\
1.28 \\
0.64 \\
0.41\end{array}$ & $\begin{array}{l}0.60 \\
1.36 \\
1.12 \\
0.56 \\
0.56\end{array}$ & $\begin{array}{l}0.54 \\
1.58 \\
0.86 \\
0.50 \\
0.56\end{array}$ & $\begin{array}{l}0.52 \\
1.60 \\
1.02 \\
0.58 \\
0.40\end{array}$ & $\begin{array}{l}0.62 \\
2.56 \\
1.02 \\
0.67 \\
0.48\end{array}$ & $\begin{array}{l}0.66 \\
1.78 \\
0.96 \\
0.44 \\
0.40\end{array}$ & $\begin{array}{l}0.62 \\
2.04 \\
0.94 \\
0.52 \\
0.40\end{array}$ & $\begin{array}{l}0.70 \\
1.56 \\
1.00 \\
0.46 \\
0.42\end{array}$ \\
\hline Mean & 0.94 & $0 \cdot 78$ & 0.94 & 0.84 & $0 \cdot 81$ & $0 \cdot 82$ & $1 \cdot 07$ & 0.85 & 0.90 & 0.83 \\
\hline Group B & 1.00 p.m. & 4.15 p.m. & 5.30 p.m. & 7.30 p.m. & 9.00 p.m. & 1.00 p.m. & 4.15 p.m. & 5.30 p.m. & 7.30 p.m. & 9.00 p.m. \\
\hline $\begin{array}{c}\text { Subject: } \\
\text { J. C. } \\
\text { L. A. } \\
\text { T. B. } \\
\text { T. W. } \\
\text { S. R. }\end{array}$ & $\begin{array}{l}0 \cdot 38 \\
0 \cdot 22 \\
1 \cdot 14 \\
3 \cdot 00 \\
0 \cdot 18\end{array}$ & $\begin{array}{l}0.41 \\
0.31 \\
1 \cdot 35 \\
4.60 \\
0.26\end{array}$ & $\begin{array}{l}0.48 \\
0.40 \\
1.00 \\
5.02 \\
0.32\end{array}$ & $\begin{array}{l}0 \cdot 32 \\
0 \cdot 14 \\
0 \cdot 88 \\
4 \cdot 05 \\
0 \cdot 18\end{array}$ & $\begin{array}{l}0 \cdot 28 \\
0 \cdot 10 \\
0 \cdot 74 \\
3 \cdot 65 \\
0 \cdot 20\end{array}$ & $\begin{array}{l}0.45 \\
0.30 \\
0.93 \\
1.70 \\
0.30\end{array}$ & $\begin{array}{l}0 \cdot 61 \\
0 \cdot 20 \\
1 \cdot 35 \\
4 \cdot 38 \\
0 \cdot 30\end{array}$ & $\begin{array}{l}0 \cdot 44 \\
0 \cdot 34 \\
1 \cdot 18 \\
4 \cdot 65 \\
0 \cdot 16\end{array}$ & $\begin{array}{l}0 \cdot 30 \\
0 \cdot 28 \\
0 \cdot 86 \\
4 \cdot 03 \\
0 \cdot 30\end{array}$ & $\begin{array}{l}0.43 \\
0 \cdot 18 \\
0.87 \\
3.80 \\
0 \cdot 19\end{array}$ \\
\hline Mean & 0.98 & $1 \cdot 39$ & $1 \cdot 44$ & $1 \cdot 11$ & 0.99 & 0.74 & $1 \cdot 37$ & $1 \cdot 35$ & $1 \cdot 15$ & 1.09 \\
\hline$\underset{\text { mean }}{\text { Grand }}$ & 0.96 & 1.09 & $1 \cdot 19$ & 0.98 & 0.90 & $0 \cdot 78$ & $1 \cdot 22^{*}$ & $1 \cdot 10$ & 1.03 & 0.96 \\
\hline
\end{tabular}

* The rise in $\% \mathrm{~N}_{2}$ after fine dust is significant $(0.001<\mathrm{p}<0.01)$. 
TABLE 6

I.M.B.C. THROUGHOUT DAYS OF EXPOSURE TO TOTAL AND TO FINE DUST

(Second Series of Tests)

\begin{tabular}{|c|c|c|c|c|c|c|}
\hline \multirow[b]{3}{*}{ Group C } & \multicolumn{6}{|c|}{ I.M.B.C. (1./min.) } \\
\hline & \multicolumn{3}{|c|}{ Exposure to Total Dust } & \multicolumn{3}{|c|}{ Exposure to Fine Dust } \\
\hline & $\begin{array}{l}12.30 \\
\text { p.m. }\end{array}$ & $\begin{array}{l}5.10 \\
\text { p.m. }\end{array}$ & $\begin{array}{l}6.30 \\
\text { p.m. }\end{array}$ & $\begin{array}{l}12.30 \\
\text { p.m. }\end{array}$ & $\begin{array}{l}5.10 \\
\text { p.m. }\end{array}$ & $\begin{array}{l}6.30 \\
\text { p.m. }\end{array}$ \\
\hline $\begin{array}{c}\text { Subject: } \\
\text { H. M. } \\
\text { C. H. } \\
\text { E. M. } \\
\text { J. M. } \\
\text { N. L. } \\
\text { R. S. }\end{array}$ & $\begin{array}{r}110.0 \\
69.0 \\
128.3 \\
112.7 \\
61.3 \\
148.3\end{array}$ & $\begin{array}{r}102 \cdot 7 \\
41 \cdot 3 \\
100 \cdot 0 \\
100 \cdot 3 \\
40 \cdot 7 \\
133 \cdot 3\end{array}$ & $\begin{array}{r}108.3 \\
59.3 \\
119.7 \\
101.7 \\
46.0 \\
128.0\end{array}$ & $\begin{array}{r}118.3 \\
71.3 \\
130.7 \\
111.0 \\
69.7 \\
147.3\end{array}$ & $\begin{array}{r}112.3 \\
48.3 \\
110.7 \\
99.0 \\
47.0 \\
134.3\end{array}$ & $\begin{array}{r}114.0 \\
65.3 \\
126.7 \\
102.0 \\
42.3 \\
136.0\end{array}$ \\
\hline Mean & 104.9 & $86 \cdot 4^{*}$ & 93.8 & $108 \cdot 1$ & 91.9* & $97 \cdot 7$ \\
\hline Group D & $\begin{array}{l}7.30 \\
\text { a.m. }\end{array}$ & $\begin{array}{l}12.00 \\
\text { noon }\end{array}$ & $\begin{array}{l}2.00 \\
\text { p.m. }\end{array}$ & $\begin{array}{l}7.30 \\
\text { a.m. }\end{array}$ & $\begin{array}{l}12.00 \\
\text { noon }\end{array}$ & $\begin{array}{l}2.00 \\
\text { p.m. }\end{array}$ \\
\hline $\begin{array}{l}\text { Subject: } \\
\text { J. C. } \\
\text { F. M. } \\
\text { T. W. } \\
\text { J. S. } \\
\text { P. S. } \\
\text { S. R. }\end{array}$ & $\begin{array}{r}139 \cdot 0 \\
116 \cdot 3 \\
69 \cdot 0 \\
124.0 \\
133.0 \\
173.3\end{array}$ & $\begin{array}{r}131.7 \\
118.3 \\
49.0 \\
118.7 \\
126.7 \\
169.0\end{array}$ & $\begin{array}{r}133.7 \\
111.7 \\
51.3 \\
120.7 \\
132.3 \\
172.3\end{array}$ & $\begin{array}{r}138.7 \\
110.7 \\
64.0 \\
114.7 \\
122.3 \\
173.3\end{array}$ & $\begin{array}{r}131.0 \\
113.3 \\
48.0 \\
116.0 \\
119.3 \\
179.3\end{array}$ & $\begin{array}{r}136.7 \\
112.0 \\
53.3 \\
123.7 \\
128.3 \\
181.0\end{array}$ \\
\hline Mean & $125 \cdot 8$ & $118.9 \dagger$ & $120 \cdot 3$ & $120 \cdot 6$ & $117 \cdot 8$ & $122 \cdot 5$ \\
\hline
\end{tabular}

* Falls in M.B.C. after both total and fine dusts are significant $(\mathrm{p}<0.001)$.

$\dagger$ Fall in M.B.C. after total dust is significant $(0.001<p<0.01)$.

but an insignificant one of $2 \cdot 8$ litres per minute after fine dust. Table 2 suggests that, in this experiment, the concentration of fine dust when the elutriators

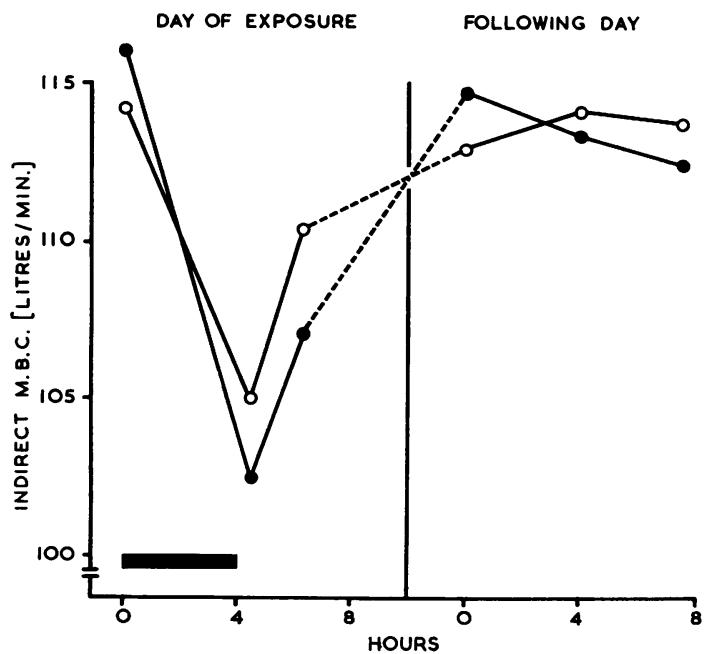

FIG. 4.-Change in I.M.B.C. (second series) caused by exposure to total dust $(\bullet)$ and fine dust $(O)$. The period of exposure is indicated by the solid block. were present was very low, and this may have been partly responsible for the small ventilatory change produced. There was no significant difference between the response of this group to total or to fine dust, and it is justifiable to plot the results for Groups C and D together (Fig. 4) in the same way as for Groups A and B. It shows, as in the earlier experiment, a change produced by total dust somewhat larger than by fine alone.

Only two readings of the inspiratory airways resistance were taken on each day. Mean results are shown in Fig. 5, and detailed findings for the days of exposure in Table 7.

The rise in airways resistance after inhalation of dust has been largely confined to five subjects in total dust and to four in fine. Taking Groups $\mathrm{C}$ and $\mathrm{D}$ together there is a significant increase in airways resistance of 0.51 unit in total dust ( $p<0.001$ ), but that of 0.24 unit in fine dust is insignificant. The difference in the two responses is not significant. The effective standard error of a single reading of the inspiratory airways resistance is \pm 0.35 unit, showing that its sensitivity in measuring the functional effects of inhaling cotton dust is lower than that of the I.M.B.C.

Relation to Byssinosis.-In the results given in Table 8 the cotton workers have been divided according to the presence or absence of symptoms of byssinosis. The physiological changes immediately following dust exposure usually appear

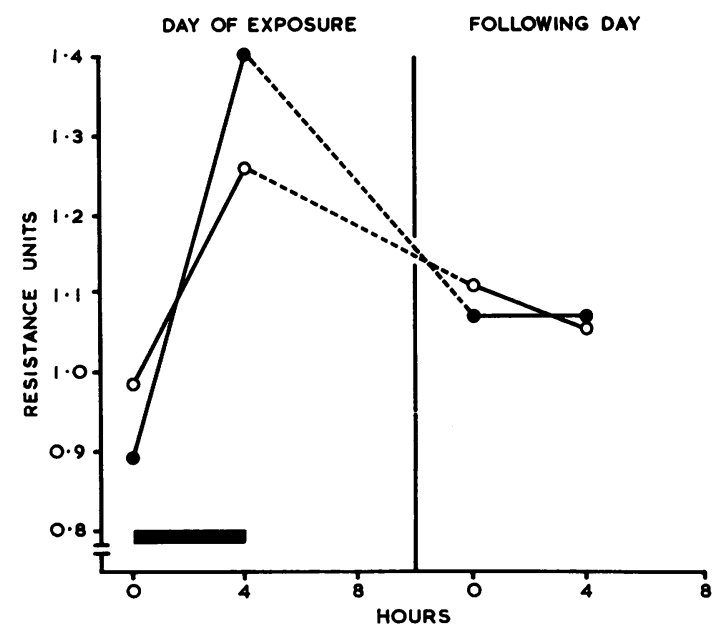

FIG. 5.-Change in inspiratory airways resistance caused by exposure to total dust $(\bullet)$ and fine dust $(O)$. The period of exposure is indicated by the solid block. 
TABLE 7

INSPIRATORY AIRWAYS RESISTANCE THROUGHOUT DAYS OF EXPOSURE TO TOTAL AND TO FINE DUST (Second Series of Tests)

\begin{tabular}{|c|c|c|c|c|}
\hline \multirow[b]{3}{*}{ Group C } & \multicolumn{4}{|c|}{ Inspiratory Airways Resistance (A.W.R. Units) } \\
\hline & \multicolumn{2}{|c|}{ Total Dust } & \multicolumn{2}{|c|}{ Fine Dust } \\
\hline & 12.30 p.m. & 5.10 p.m. & 12.30 p.m. & 5.10 p.m. \\
\hline $\begin{array}{l}\text { Subject: } \\
\text { H. M. } \\
\text { C. H. } \\
\text { E. M. } \\
\text { J. M. } \\
\text { N. L. } \\
\text { R. S. }\end{array}$ & $\begin{array}{l}1.56 \\
0.87 \\
0.93 \\
0.67 \\
0.68 \\
0.65\end{array}$ & $\begin{array}{l}3.12 \\
1.96 \\
1.47 \\
0.61 \\
1.62 \\
0.69\end{array}$ & $\begin{array}{l}1.14 \\
1.20 \\
1.58 \\
0.89 \\
0.58 \\
0.64\end{array}$ & $\begin{array}{l}0.99 \\
1.83 \\
1.28 \\
0.78 \\
2.01 \\
0.51\end{array}$ \\
\hline Mean & 0.89 & $1 \cdot 58$ & 1.01 & $1 \cdot 23$ \\
\hline Group D & 7.30 a.m. & 12.00 noon & 7.30 a.m. & 12.00 noon \\
\hline $\begin{array}{l}\text { Subject: } \\
\text { J. C. } \\
\text { F. M. } \\
\text { T. W. } \\
\text { J. S. } \\
\text { P. S. } \\
\text { S. R. }\end{array}$ & $\begin{array}{l}0.55 \\
0.86 \\
1.38 \\
1.28 \\
0.82 \\
0.46\end{array}$ & $\begin{array}{l}0.64 \\
0.87 \\
3.47 \\
0.88 \\
0.62 \\
0.85\end{array}$ & $\begin{array}{l}0.78 \\
1.08 \\
1.74 \\
0.78 \\
0.66 \\
0.71\end{array}$ & $\begin{array}{l}0.78 \\
1.05 \\
2.54 \\
0.85 \\
1.16 \\
0.94\end{array}$ \\
\hline Mean & 0.89 & $1 \cdot 22$ & 0.96 & 1.22 \\
\hline$\underset{\text { mean }}{\text { Grand }}$ & 0.89 & $1 \cdot 40^{*}$ & 0.99 & $1 \cdot 23$ \\
\hline
\end{tabular}

* Increase in A.W.R. after total dust is significant $(p<0.001)$.

TABLE 8

PHYSIOLOGICAL CHANGES IMMEDIATELY FOLLOWING DUST EXPOSURE IN COTTON WORKERS WITH AND WITHOUT BYSSINOSIS

\begin{tabular}{|c|c|c|c|c|}
\hline \multirow[b]{3}{*}{$\begin{array}{l}\text { Total dust: } \\
\text { No byssinosis } \\
\text { Byssinosis }\end{array}$} & \multicolumn{2}{|c|}{ First Series of Tests } & \multicolumn{2}{|c|}{ Second Series of Tests } \\
\hline & $\begin{array}{l}\text { I.M.B.C. } \\
\text { (I./min.) }\end{array}$ & $\mathrm{N}_{2}(\%)$ & (1./min.) & $\begin{array}{l}\text { A.W.R. } \\
\text { (Units) }\end{array}$ \\
\hline & $\begin{array}{l}-9 \cdot 8^{*} \\
-14 \cdot 6^{*}\end{array}$ & $\begin{array}{r}0.03 \\
+0.25\end{array}$ & $\begin{array}{r}8.3^{*} \\
-16.7^{*}\end{array}$ & $\begin{array}{l}+0.35 \\
+0.71^{*}\end{array}$ \\
\hline $\begin{array}{l}\text { Fine dust: } \\
\text { No byssinosis } \\
\text { Byssinosis }\end{array}$ & $\begin{array}{l}=9 \cdot 7^{*} \\
-9 \cdot 8^{*}\end{array}$ & $\begin{array}{r}+0.19 \\
+0.89\end{array}$ & $\begin{array}{l}-7 \cdot 2^{*} \\
-13 \cdot 0^{*}\end{array}$ & $\begin{array}{l}+0.06 \\
+0.43\end{array}$ \\
\hline
\end{tabular}

* Changes significant at $2 \%$ level or less.

First series of tests: four subjects with and four without byssinosis. Second series of tests: six subjects with and four without byssinosis.

greater in the men with byssinosis, but in these small groups the difference does not attain statistical significance.

\section{Discussion}

In both series of tests the ventilatory capacity was reduced on the average slightly more when dust of the whole particle size range was inhaled than when particles of over $7 \mu$ were excluded, but this difference was not significant in any group. There was a significant response to the fine fraction alone in all subjects except Group D which was relatively unresponsive to unfiltered dust as well. The nitrogen clearance index and the inspiratory airways resistance were not sensitive indices of change in most subjects, but their general pattern followed that of the ventilatory capacity.

It has been demonstrated previously that changes in ventilatory capacity during the day are normally very slight and we can conclude from the present experiments that the fine fraction of cotton mill dust has produced physiological effects; furthermore, these experiments suggest that this fraction alone may be responsible. The slightly larger effects of unfiltered dust can be explained by the somewhat greater weight of fine particles in it. The pharmacological examination of the dust suggests that its biological activity is unrelated to particle size.

Roach and Schilling (1960) state the possibility that fine dust may affect the smaller airways without causing symptoms, while the larger particles may produce the sensation of chest tightness by their presence in the upper airways. In our first series of tests three subjects mentioned chest tightness after exposure to total dust and three after the fine alone. In these experiments the elutriators were out of sight of the subjects. In the second series seven mentioned some chest tightness in total dust and only one when the elutriators were in position, but as they were visible one cannot exclude the possibility that their presence provided reassurance.

The physiological findings are of interest in suggesting a direct action by the dust or a constituent of it on the smaller air passages. Had the action been indirect, for instance via the blood stream, one would have expected the total dust which was some 10 times heavier to have had a much larger effect than fine. Our findings imply that, to be effective, dust suppression measures should remove fine particles. If dust over $7 \mu$ is chiefly responsible for the clinical effects of byssinosis, filtration of the larger particles only could perhaps suppress these symptoms while leaving physiological effects which may ultimately lead to the permanent respiratory damage which is a feature of the disease (Schilling et al., 1955). Further research is needed to determine the long-term effects of cotton dust exposures causing daily impairment in respiratory function and to determine the effects of the coarser dust on its own.

We thank Mr. P. D. Oldham for the statistical analysis, and Miss Anne Davenport and Professor W. D. M. Paton for assessing the biological activity of dust samples. We are grateful to the management of the cotton mill, to the volunteers who took part in the investigation, and to Miss Pamela Edwards and Mr. R. Pryce who provided technical assistance. 


\section{REFERENCES}

Clements, J. A., Sharp, J. T., Johnson, R. P., and Elam, J. O. (1959). J. clin. Invest., 38, 1262.

Comroe, J. H., and Fowler, W. S. (1951). Amer. J. Med., 10, 408. Davenport, A., and Paton, W. D. M. (1962). Brit. J. industr. Med., $19,19$.

Gielen, E. (1957). Action des poussières et d'agents pharmacodynamiques sur la fonction respiratoire, Sème partie: Action des Aérosols d'aleudrine chez 311 mineurs encore au travail. Institut d'Hygiène des Mines, Hasselt. Communication No. 145.

Kay, J. P. (1831). New Engl. med. surg. J., 1, 357.

Kennedy, M. C. S. (1953). Thorax, 8, 73.

Lewinsohn, H. C., Capel, L. H., and Smart, J. (1960). Brit. med. J., $1,462$.
McKerrow, C. B., McDermott, M., and Gilson, J. C. (1960). Lancet, $1,149$.

15,75 .

Middleton, E. L. (1932). Home Office: Report of the Departmental Committee on Dust in Card Rooms in the Cotton Industry. H.M.S.O., London.

Olsen, H. C., and Gilson, J. C. (1960). Brit. med. J., 1, 450.

Prausnitz, C. (1936). Spec. Rep. Ser. med. Res. Coun. (Lond.). No. 212.

Roach, S. A., and Schilling, R. S. F. (1960). Brit. J. industr. Med. $17,1$.

Schilling, R. S. F., Hughes, J. P. W., Dingwall-Fordyce, I., and Gilson, J. C. (1955). ibid., 12, 217.

Shephard, R. J. (1959). J. Physiol., 145, 459.

Wright, B. M. (1954). Brit. J. industr. Med., 11, 284. 